\title{
Techno-Economic Analysis of a Microgrid System To Increase Electricity Access in Rural Areas
}

\author{
Sunario Manalu, and Charles O. P. Marpaung*
}

\begin{abstract}
This study analyses the technical and economic performances of a microgrid system which is used to increase the electricity access in a rural area - Hutajulu village, Parmonangan district, North Tapanuli district, Indonesia. There are two types of power distributed generator used in the microgrid system, i.e., diesel generator and solar $\mathrm{PV}$, and there are 20 houses in the village to be supplied electricity by the microgrid system. The results show that the generator would operate 3.754 hours per year and would supply electricity to the houses $2,456 \mathrm{kWh} / \mathrm{year}$ during the planning horizon (25 years). The levelized cost of electricity (LCOE) of the diesel generator would be $U S ₫ 10.7 / \mathrm{kWh}$, and the capacity factor of the diesel generator would be $14 \%$. The average electrical efficiency of the diesel generator is found $27.2 \%$. In case of the solar PV installed in the microgrid system, the operating hour of the solar PV during the planning horizon would be 4,426 hours/year and supplies electricity to the houses $2,153 \mathrm{kWh} /$ year. The levelized cost of electricity of the solar PV would be $\mathrm{US} \not \mathbf{7 . 9 2 / k W h}$.
\end{abstract}

Index Terms-Microgrid, Photovoltaic, Electricity Access, Rural Area, Techno-Economic Analysis.

\section{INTRODUCTION}

$\mathrm{T}$ HE concept of microgrid was first developed by R. H. Lasseter in 2002 [1]. Microgrid is a distributed generation pattern that encompasses a variety of energy sources, ranging from clean and efficient fossil-fuels technologies (such as micro-turbines), as well as from environmentally friendly renewable energy technologies such as photovoltaics, fuel cells, wind, biogas, hydro. Combination of different but complementary energy generation systems based on renewable or mixed energy (renewable energy with backup bio-fuel/diesel generator) are known as a renewable energy hybrid system. The grid formed by this system is known as a micro-grid due to its size compared to thr main grid. The renewable energy technologies generate many environmental and economic benefits. By definition, they do not use fossil fuels, which means they generate low or zero greenhouse gas emissions and less pollution. Investments in renewable technologies bring the added benefit of stimulating employment and economic growth, which move the world closer to a low-carbon economy [2,3].

Manuscript received August 14, 2019; revised September 18, October 9, 2019, accepted October 30, 2019.

Sunario Manalu is an alumni of Department of Electrical Engineering, Universitas Kristen Indonesia (UKI), Jakarta (e-mail: sunario@gmail.com)

Charles O.P. Marpaung is with the Department of Electrical Engineering, Universitas Kristen Indonesia (UKI), Jakarta, Indonesia, (e-mail: cop.marpaung@gmail.com).

*Corresponding author.
Given the growing gap between energy supply and demand, renewable energy has assumed a critical role in meeting the rising demand for energy, especially by industry, in developing countries. Several renewable energy technologies have emerged as economically viable and environmentally friendly options, which if suitably adopted, can meet growing energy needs of industry, and particularly of small and medium-sized enterprises (SMEs). When designing a hybrid system for the production of electrical energy, various aspects have to be considered, such as cost and environmental impact $\left(\mathrm{CO}_{2}\right.$ emission). Availability and reliability will be, however, among the key issues [4]. Microgrid electricity network is an interconnection network system from various energy sources distributed into a small network that can operate independently or connected to the main or national grid to enable it to operate in both grid-connected or island-mode.

Worldwide, more than 1.1 billion people remain without access to electricity. Hundreds of millions more live with insufficient or unreliable electricity. This forces people to rely on expensive and environmentally hazardous diesel or oil for energy. Meanwhile, 2.9 billion people still rely on traditional fuels like solid fuels such as wood, animal dung, and charcoal for cooking and heating and often have poor ventilation in their homes. Nearly 2 million people die each year from pneumonia and chronic lung disease from using these fuels. Switching to renewable energy sources will reduce indoor air pollution, improving health and quality of life for millions around the world. It will also strengthen energy security, which will boost economic growth and help reduce poverty. Enhancing access to modern and reliable energy supplies is widely regarded as a prerequisite for economic development in developing countries and countries with economies in transition. For such development to be sustainable, this energy must be used to promote productive uses that create jobs and more incomegenerating opportunities for local communities.

Affordable energy supplies are crucial to economic growth in both developed and developing countries - to power homes, connect communities, provide safe water and promote economic and human development. Microgrid can be used to enhnace access to electricity in area which are not covered by the national electricity transmission and distribution network.

Many remote areas in Indonesia are still not electrified. Even if it is already electrified, the connected power capacity is still small. As a result, eletrical energy use per area $\left(\mathrm{kWh} / \mathrm{m}^{2}\right)$ is still small, or the electrical energy use per occupant ( $\mathrm{kWh} /$ occupant) is still low. This paper analyze the technical and economic performance of the microgrid system if it is used to increase the electricity access in a rural are, i.e., Hutajulu village, 
Parmonangan sub-district, North Tapanuli District.

The paper is organized as follows. A description of the methodology used in this study is presented in the next section followed by the input data and assumptions. The results and discussions are examined in the subsequet sections. Finally, the major findings of the study are summarized.

\section{Methodology}

This study uses The HOMER Pro® microgrid software to analyse the technical and economic performance of the microgrid system. The HOMER Pro® microgrid software by HOMER Energy is the global standard for optimizing microgrid design in all sectors, from village power and island utilities to grid-connected campuses and military bases. Originally developed at the National Renewable Energy Laboratory, and enhanced and distributed by HOMER Energy, HOMER (Hybrid Optimization Model for Multiple Energy Resources) nests three powerful tools in one software product, so that engineering and economics work side by side. At its core, HOMER is a simulation model. It will attempt to simulate a viable system for all possible combinations of the equipment that you wish to consider. Depending on how you set up your problem, HOMER may simulate hundreds or even thousands of systems. HOMER simulates the operation of a hybrid microgrid for an entire year, in time steps from one minute to one hour. HOMER examines all possible combinations of system types in a single run, and then sorts the systems according to the optimization variable of choice. HOMER Pro features our new optimization algorithm that significantly simplifies the design process for identifying least-cost options for microgrids or other distributed generation electrical power systems. HOMER Optimizer ${ }^{\mathrm{TM}}$ is a proprietary "derivative free" optimization algorithm that was designed specifically to work in HOMER. HOMER lets you ask as many "What if?" questions as you'd like, because you cannot control all aspects of a system, and you cannot know the importance of a particular variable or option without running hundreds or thousands of simulations and comparing the results. HOMER makes it easy to compare thousands of possibilities in a single run. This allows you to see the impact of variables that are beyond your control, such as wind speed, fuel costs, etc, and understand how the optimal system changes with these variations. HOMER Pro can be customized with up to 9 individual modules to meet your specific modeling needs, i.e.,: Biomass, Hydro, Combined Heat \& Power, Advanced Load, Advanced Grid, Hydrogen, Advanced Storage, Multi-Year, MATLAB Link [5].

There are several steps to analyze the microgrid planning that will be used in rural areas is shown in Figure I and can be explained as follows:

1. Determine the total burden on residential homes.

The data of amount of burden is needed by counting the number oh houses in the Hutajulu village and the types load of each houses. It is also important to know the hourly used of each type of load in each house. From this data we can know the peak load data per day.

2. Selecting the microgrid system energy source model.
After the total power is calculated, the next process is the selection of energy source models that will be installed to serve the electrical load in the Hutajulu village. In this study, the variation of energy source that will be installed is solar $\mathrm{PV}$ and diesel generator [6,7].

3. Analysis of energy generated.

After selecting the hybrid power plant system that is suitable for serving the load in the village of Hutajulu, the the capacity of the plants are determined and analyze the energy generated from the plants by using the Homer Pro application.

4. Cost analysis of microgrid systems.

The cost analysis is conducted after running the Homer Pro application. The analysis of the cosct includes the levelized cost of electricity (LCOE) of the solar PV and diesel generator, the total cost during the life time of the microgrid, the cost of the fuel used by the generator, the break down of the toal cost into replacememt cost, fuel cost, opearing cost, capital cost, and salvage value [8].

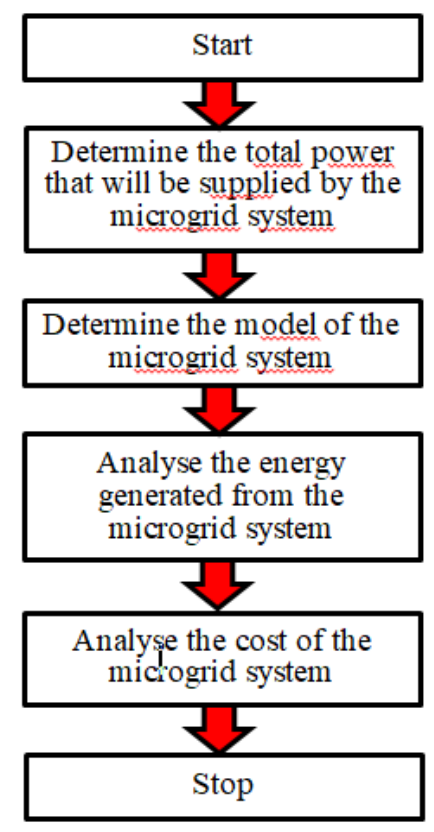

Fig. 1. Flowchart of Microgrid Planning

\section{INPUT DATA AND ASSUMPTIONS}

Hutajulu village (desa) is located in Parmonangan sub-district (kecamatan), North Tapanuli district (kabupaten), North Sumatera provinve, Indonesia as shown in Fig. 2. The area of Parmonangan sub-district is $257.35 \mathrm{~km}^{2}$, and the population density is 52 population $/ \mathrm{km}^{2}$. There are 14 villages in Parmonangan sub-district, one of the villages is Hutajulu. There are 20 houses in Hutajulu villages, and each house uses different types of electrical devices, and accordingly, the total power and energy use are also different from one house to another house.

Altough Hutajulu village has been connected to the national (PT. PLN grid), however, the electrical energy consumption per capita is very low. The daily load profile of the total 20 houses in Hutajulu village can be seen in Fig. 3. 


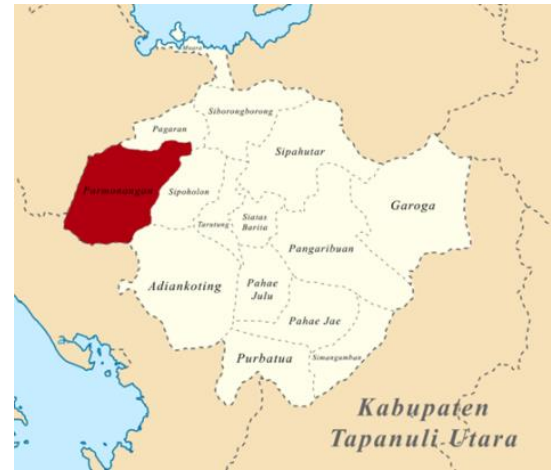

Fig. 2. Map of Hutajulu Village, Parmonangan sub-district, North Tapanuli district.

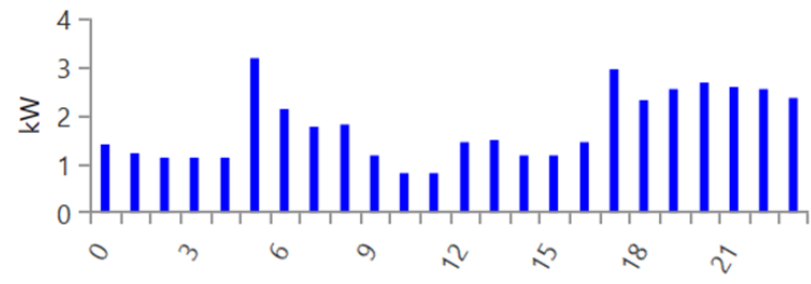

Fig. 3. Daily load profile in Hutajulu Village, Parmonangan sub-district, North Tapanuli district.

Hutajulu village is located at latitude $2^{\circ}, 4.6^{\prime} \mathrm{N}$ and longitude $98^{\circ}, 49.2^{\prime} \mathrm{E}$. The solar data measured in the are can be seen in Table I.

TABLE I

Clearness INDEX AND DAILY RADIATION AT HutaJUlu VillaGE

\begin{tabular}{ccc}
\hline Month & $\begin{array}{c}\text { Clearness } \\
\text { Index }\end{array}$ & $\begin{array}{c}\text { Daily Radiation } \\
\left(\mathrm{kWh} / \mathrm{m}^{2} / \text { day }\right)\end{array}$ \\
\hline Jan & 0.479 & 4.710 \\
Feb & 0.497 & 5.090 \\
Mar & 0.471 & 4.930 \\
Apr & 0.462 & 4.760 \\
May & 0.487 & 4.790 \\
Jun & 0.501 & 4.770 \\
Jul & 0.479 & 4.610 \\
Aug & 0.451 & 4.530 \\
Sep & 0.427 & 4.420 \\
Oct & 0.425 & 4.360 \\
Nov & 0.421 & 4.160 \\
Dec & 0.452 & 4.370 \\
\hline Annual Average Daily Radiation $=$ \\
\multicolumn{3}{c}{$4.63 \mathrm{kWh} / \mathrm{m}^{2} /$ day } \\
Source: [9] & \multicolumn{3}{l}{}
\end{tabular}

In addition to the two types of generators i.e., solar PV and diesel generator, installed in the microgrid system, there are also several supporting components installed together with the generators. The main supporting components are inverters, energy storage in the form of batteries, and ATS (Automatic Transfer Switch). The solar PV used in this study is Flat Plate LONGi LR6-60 BP solar cells with a capacity of $0.305 \mathrm{~kW}$, $18.7 \%$ efficiency and module area (H/W/D) 1650x991x40 mm, and lifetime 25 years (Source: Solaris Technology Industry, Alibaba and Zerohomebills). The type of diesel generator is HP $6700 \mathrm{LN}$ with a capacity of $2 \mathrm{~kW}$ (source: Indotara.co.id, Bukalapak.com, inkuiri.com). The solar price used for the generator is taken from BPH Migas [10]. The type of converter is PRETTL REFU sol $08 \mathrm{~K}$ with a capacity of $2 \mathrm{~kW}$, inverter efficiency $97.30 \%$, and lifetime 25 years. The type of energy stirage is Trojan SSIG 12 255, $12 \mathrm{~V}$, nominal capacity 3.09 kWh, maximum capacity 257 Ah (sources: Trojan Battery Company, renvu.com, Battery Heaven \& Solar Solution, phtotovoltaicshop.com). The Automatic Transfer Switch (ATA) consists of inverter with capacity 2.000Watt (MSW), intelligent 4 step smart charger, and control unit ATS.

\section{RESULTS AND DISCUSSIONS}

The microgrid system in this study uses two types of power plants, i.e., solar PV and diesel generator. The system is supported by other components such as batteries and converters so that the microgrid system can serve the needs of the load. The system configuration can be seen in Figure IV.

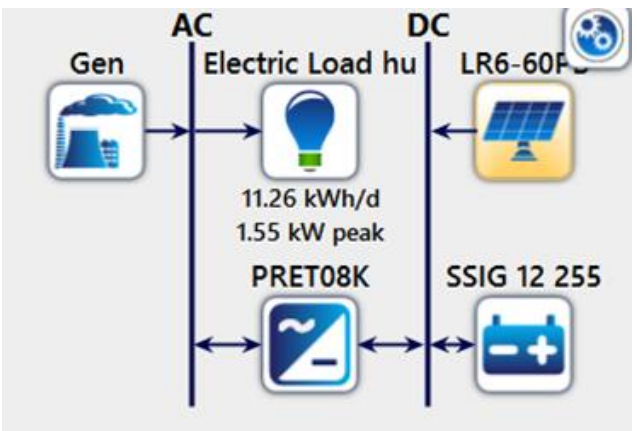

Fig. 4. Configuration with two PLTS and Generator sources.

The battery is used to store the electrical energy produced by the diesel generator and solar PV. The converter is used as an $\mathrm{AC}$ and DC bus connector, it can also be called an inverter when changing the DC electricity generated by PLTS to supply AC loads. The converter also functions as a rectifier when changing AC electricity generated by the diesel generator to DC to supply the DC load or charge the battery. So, the converter in the microgrid system can operate in two modes, i.e., from an inverter to a rectifier, and vice versa.

The microgrid system which consist of PV and generator would supply $42.6 \mathrm{kWh}$ electricity per day to the all houses in the Hutajulu village. The diesel generator would work 3,754 hours / year to adjust to load requirements due to fluctuating weather that affects energy production from the solar PV. The cost of producing electricity (levelized cost of electricity or LCOE) from the diesel generator would be US $₫ 10.7 / \mathrm{kWh}$ and the capacity factor is $14 \%$. The mean of electrical efficiency of the diesel generator is found $27.2 \%$. The specific fuel consumption of the diesel generator would be 0.374 litre/kWh. The energy generated from the diesel generator would be 2,456 $\mathrm{kWh}$.

Regarding with the solar PV installed in the microgrid, the average energy generated from PV would be $5.90 \mathrm{kWh} /$ day, so in one year, the energy generated would be $2,153 \mathrm{kWh} /$ year. The capacity factor of the PV would be $13.1 \%$. The total hours of operation of the PV would be 4,426 hours/year, and the levelized cost of electricity (LCOE) of the PV would be $\mathrm{US} \not 7.94 / \mathrm{kWh}$. 
The total electrical energy generated from the generator and $\mathrm{PV}$ in one year would be $4,608 \mathrm{kWh}$; around $46.7 \%$ (or 2,153 $\mathrm{kWh}$ ) would be from the solar PV, and the remaining, i.e. 53.3\% (or 2,456 kWh) would be from the diesel generator. The monthly energy production from the diesel generator and the solar PV, can be seen in Figure V.

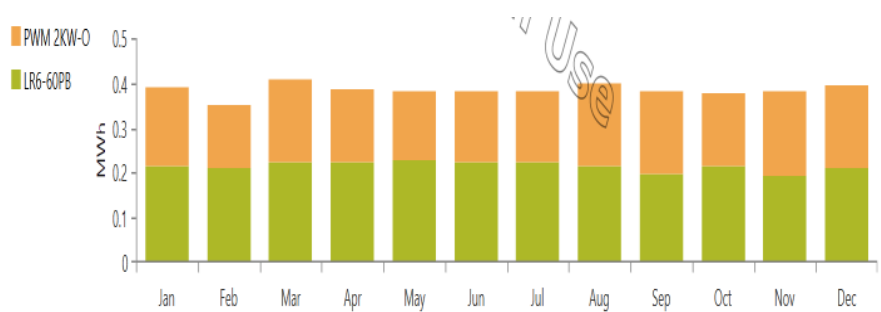

Fig. 5. Monthly average of energy production from PV and generator.

Figure VI shows the annual expenditure of the microgrid system during 25 years (the life time of the microgrid system is expected 25 years). Figure VI also shows the break down of the annual expenditure into replacement-, fuel-, salvage-, operating-, and capital- costs. Figure 4 shows that the largest expenditure was in the first year to purchase the devices and components to support the system i.e. US\$ 3,344.33, then followed by the annual cost of replacing fuel on the generator for US\$ 380.83 and annual maintenance and operating costs of the system US\$194.27. The replacement cost is only for the battery used in the system, where the battery should be replaced periodically at a price of US\$ 720.28 per replacement. In the $25^{\text {th }}$ year, there would be an income of US\$ 191.76 from the residual value of batteries, while diesel generator, solar PV and converter have no value because the age of the components are only up to 25 years. With these costs for the village of Hutajulu no longer depends on electricity from PT. PLN, because the load demand has been served by the microgrid system.

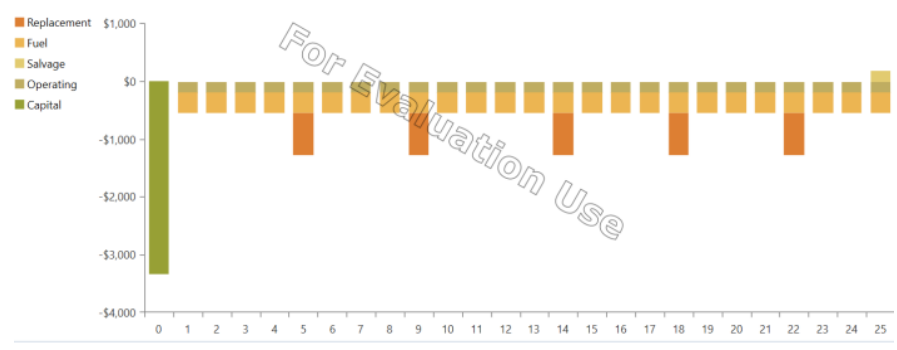

Fig. 6. Annual expenditure of the Microgrid system during 25 years.

Table II shows the cost of the microgrid system during 25 years of service life. Of the total cost of the system, $53.62 \%$ is the cost of generator, $22.34 \%$ is the cost of batery, $15.88 \%$ is te cost of solar PV, and the remaining $8.16 \%$ is the cost of converter. The cost of generator consists of the capital cost, O\&M cost, and fuel cost. Of the three costs, the fuel cost is the highest, i.e., $70.8 \%$, and then followed by the fuel cost and capital cost $22.1 \%$ and $7.1 \%$ respectively. The cost of solar PV consists of capital cost and O\&M cost, i.e., 59.15\% and 40.85\% respectively. The cost of converter is only capital cost. For the case of batery component, there will be salvage value of the batery at the end of the service year. In Table II, the salvage value is negative which means that it is the value of the battery and become an income at the end of the service years. The cost of the battery consists of capital cost, replacement cost, and O\&M cost. The share of the replacement cost is the highest i.e., $66.03 \%$. and then followed by the capital cost and the O\&M cost $26.34 \%$ and $9.42 \%$ respectively. The replacement cost of the battery is high because the battery should be replaced with the new one periodically during the planning horizon.

TABLE II

MICROGRID SYSTEM COST DATA DURING 25 YEARS OF SERVICE LIFE

\begin{tabular}{lcrrrrc}
\hline Component & $\begin{array}{c}\text { Capital } \\
(\$)\end{array}$ & Replacement & $\begin{array}{c}\text { O\&M } \\
(\$)\end{array}$ & $\begin{array}{c}\text { Fuel } \\
(\$)\end{array}$ & $\begin{array}{c}\text { Salvage } \\
(\$)\end{array}$ & $\begin{array}{c}\text { Total } \\
(\$)\end{array}$ \\
\hline Generator & 468.26 & 0 & $1,455.90$ & $4,664.70$ & & $6,588.86$ \\
Solar PV & $1,153.77$ & 0 & 769.93 & 0 & & $1,950.70$ \\
Converter & $1,002.02$ & 0 & 0 & 0 & & $1,002.02$ \\
Battery & 720.28 & $1,812.96$ & 258.55 & 0 & -45.94 & $2,745.56$ \\
\hline System & $3,344.33$ & $1,812.96$ & $2,511.38$ & $4,664.70$ & -45.94 & $12,287.47$ \\
\hline
\end{tabular}

\section{CONCLUSION AND FINAL REMARKS}

This study analyse how to design a microgrid to increase electricity access in a rural area, i.e., Hutajulu village. The microgrid is design to supply electricity for 20 houses in the village. There are two power generators are installed in the micro grid, i.e., diesel generator and solar PV. Supporting devices, such as converter and battery are also installed in the microgrid. The results show that to supply electricity $2,456 \mathrm{kWh}$ per year, the generator would operate 3,754 hours per year. The cost of producing electrity from the generator would be US $410.7 / \mathrm{kWh}$ and the capacity factor would be $14 \%$. The electrical effciency of the generator is found $27.2 \%$. From the solar PV side, the average energy generated would be 2,153 $\mathrm{kWh} /$ year, and the total hours of operation would be 4,426 hours/year, and the levelized cost of the solar PV would be US $₫ 7.94 / \mathrm{kWh}$. The results show that the electricity generated from the generator (53.3\%) is still higher than that from the PV $(46.7 \%)$. The results indicate that the electricity need for the Hutajulu village could be fully supplied by the microgrid system. However, it is important to explore other types of renewable energy which are available in the village to reduce the electrucity generated from the diesel generator. For example, electricity generated from wind turbine, biomass, etc.

\section{REFERENCES}

[1] Lasseter, R. H. (2004), Microgrid: a conceptual solution, IEEE Annual Power Electronics Specialists Conference 6:4285 - 4290 Vol.6.

[2] Industrial Economics Incorporated (2015), Analyzing the Costs and Benefits of Community Microgrids, IEI, USA.

[3] Singh, P. K. (2107), Technical and Economic Potential of Microgrids in California, Master Thesis, Hamboltd State University.

[4] Vera, Y. E. G., Lopez, R. D., Agustin, D. L. L. (2019), Energy management in microgrids with renewable energy sources: a literature review, Appl. Sci., Vol. 9, pp. 3854.

[5] Homer Energy (2019), Homer Pro, https://www.homerenergy.com/ products/pro/index.html

[6] Kemenristekdikti 92017), “Rencana Umum Energi Nasional (RUEN), Peraturan Presiden Nomor 22 Tahun 2017"

[7] Planas, E., Andreu, J., Garate, J. I., de Alegria, I. M., Ibarra, E. (2015), AC and DC technology in microgrids: A review, Renewable and Sustainable Energy Reviews, Vol. 43, pp. 726-749. 
[8] El-Shimy, M.. (2017), Economics of Variable Renewable Sources for Electric Power Production., Saarbrücken: Lambert Academic Publishing.

[9] BMKG (2019), Data Online - Pusat Database BMKG, http://dataonline. bmkg.go.id/home

[10] BPH Migas (2019), BBM Satu Harga, https://www.bphmigas.go.id/ bbmsatu-hargal

\section{BIOGRAPHIES}

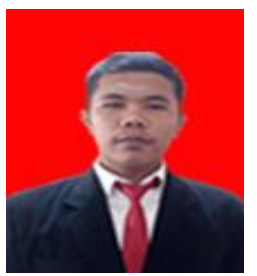

Sunario Manalu is an alumni of Department of Electrical Engineering, Universitas Kristen Indonesia. His research of interest are in the area of variable renewable energy and power system planning.

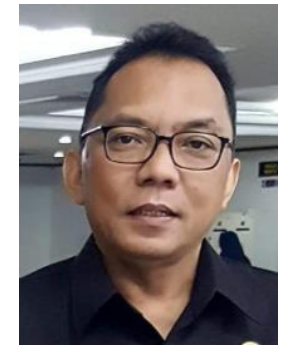

Charles O. P. Marpaung graduated from the Bandung Institute of Technology-Indonesia in 1986 with a B.Sc. degree in Electrical Engineering. He obtained his M.S. degree in Applied Statistics from the Bogor Agricultural University-Indonesia in 1990. His Ph.D. degree (1998) is in Energy Economics and Planning from the Asian Institute of Technology-Thailand. Charles O. P. Marpaung is a Full Professor in the Department of Electrical Engineering, Universitas Kristen Indonesia. He has been a Visiting Faculty

at the Department of Electrical and Electronics Engineering, Sophia University, Tokyo-Japan and also at the Energy Field of Study of the Asian Institute of Technology from 2009-2013. His areas of interest are environmental and economic implications of utility planning and energy-economy modeling. He has authored several technical papers and reports in these areas and some have been published in international refereed journals, such as Energy Policy, Energy the International Journal, RERIC International Energy Journal, and International Journal of Global Energy Issues. He is also a reviewer of Energy Policy and Energy the International Journal. Charles O. P. Marpaung is an alumni of The National Resilience Institute of the Republic of Indonesia. 